\title{
First record of entomopathogenic Beauveria bassiana (Ascomycota: Hypocreales) on pleasing fungus beetle Episcapha quadrimacula (Coleoptera: Erotylidae) in Malaysia
}

\author{
Y.K. Goh, ${ }^{1}$ T.M. Teo, ${ }^{1}$ N.F. Marzuki, ${ }^{1}$ S.S. Tan, ${ }^{1}$ R. Subramanian, ${ }^{2}$ I. Hasim, ${ }^{1}$ Y.K. Goh, ${ }^{1}$ K.J. Goh ${ }^{1}$ \\ ${ }^{1}$ Advanced Agriecological Research Sdn Bhd, Petaling Jaya, Selangor Darul Ehsan, Malaysia; \\ ${ }^{2}$ Advanced Agriecological Research Sdn Bhd, Paloh, Johor, Malaysia
}

\begin{abstract}
The presence of entomopathogenic Beauveria bassiana on Pleasing Fungus Beetle Episcapha quadrimacula has been reported on fruiting bodies of Ganoderma boninense for the first time in Malaysia.
\end{abstract}

\section{Short paper}

Erotylidae, also known as pleasing fungus or spore-feeding beetles, is a family of beetles comprising mainly of detritus- and fungus-associated beetle species. Furthermore, Erotyliids were proposed to have little to no economic importance in most parts of the world (Mishra \& MeyerRochow, 2006). In a few studies conducted in oil palm plantations with palms attacked by Ganoderma boninense or basal stem rot (BSR) disease, Episcapha quadrimacula beetles from the family of Erotylidae were reported to be one of the most common insects found to propagate in the fruiting bodies of $G$. boninense. More than $80 \%$ of the $E$. quadrimacula larvae were reported with $G$. boninense basidiospores (Chung, 2011; Seman, 2013). Dispersal of the basidiospores was proposed not only by

\footnotetext{
Correspondence: Yit Kheng Goh, Advanced Agriecological Research Sdn Bhd, No. 11 Jalan Teknologi 3/6, Taman Sains Selangor 1, Kota Damansara, 47810 Petaling Jaya, Selangor Darul Ehsan, Malaysia.

Tel: +603.61517924 - Fax: +603.61517081

E-mail: gohykheng@aarsb.com.my
}

Key words: Basidiomata; $\beta$-tubulin; Ganoderma boninense; ITS; oil palm.

Acknowledgements: we would like to thank Boustead Plantations Holdings and Kuala Lumpur Kepong Berhad for their permission and financial support to the project.

Received for publication: 20 August 2015.

Revision received: 4 April 2016.

Accepted for publication: 7 April 2016

(C) Copyright Y.K. Goh et al., 2016

Licensee PAGEPress, Italy

Journal of Entomological and Acarological Research 2016; $48: 5492$

doi:10.4081/jear.2016.5492

This article is distributed under the terms of the Creative Commons Attribution Noncommercial License (by-nc 4.0) which permits any noncommercial use, distribution, and reproduction in any medium, provided the original author(s) and source are credited. mean of winds and could also be assisted by insects, namely $E$. quadrimacula (Chung, 2011; Seman, 2013). However, the information related to the aids of $E$. quadrimacula in moving or transferring basidiospores from palm to palm and spread of Ganoderma disease is limited.

In 2014, Ganoderma fruiting bodies were collected in Paloh Oil Palm Estate, Paloh, Johor $\left(2^{\circ} 13^{\prime} \mathrm{N}, 103^{\circ} 12^{\prime} \mathrm{E}\right)$. Approximately $2-3 \%$ of the fruiting bodies collected ( $\mathrm{n}=60$ fruiting bodies collected) had fungalinfested $E$. quadrimacula (Figure 1A-B). All the infested E. quadrimacula beetles collected were sent to pathology laboratory for isolation. Beauveria bassiana was isolated from these infested beetles (Figure 1C-D). To the best of our knowledge, this is the first record of $B$. bassiana reported from $E$. quadrimacula beetles in Malaysian oil palm plantation (Farr \& Rossman, 2015).

DNA of the pure culture was extracted (FastDNA Spin Kit, MP Biomedicals, USA) from 2-week-old B. bassiana isolate grown on MEA. The internal transcribed spacers (ITS) of the rDNA and $\beta$-tubulin gene were amplified separately and sequenced (Macrogen, Korea). Similarity search and analyses were conducted using the BLAST search algorithm in NCBI GenBank. The sequences with accession number of KT183365 ( $\beta$-tubulin) and KT183365 (ITS) showed 100\% similarity with $B$. bassiana (JN713134) and 99\% similarity with $B$. bassiana (AY334537) using $\beta$-tubulin gene and ITS regions, respectively. Sequences from this study were combined with other existing sequences from GenBank were analysed using Neighbour Joining approach and B. bassiana isolate from current study clustered with other existing $B$. bassiana isolates (Figure 2A-B). Furthermore, based on both morphological characteristics and phylogenetic analysis, this current Beauveria isolate is identified as B. bassiana.

Pathogenicity study was conducted using the current $B$. bassiana isolate in triplicate ( 5 beetles per replicate). Beetles were sprayed with approximately $100 \mu \mathrm{L}$ of conidial suspension $\left(5 \times 10^{6}\right.$ conidia $\left./ \mathrm{mL}\right)$. A separate set of beetles were sprayed with sterile water and acted as control. All the beetles were placed in a moist chamber and kept at $24 \pm 2{ }^{\circ} \mathrm{C}$ for 2 weeks. Treated dead beetles were transferred to sterile Petri dishes with moistened filter papers at $24^{\circ} \mathrm{C}$ and observed for signs of conidial formation. Control beetles showed no external mycelia (Figure 1E-F). Beauveria bassiana was re-isolated only from the infested beetles to satisfy Koch's postulates (Figure 1E-F).

In conclusion, E. quadrimacula beetles are susceptible to the infestation by $B$. bassiana, demonstrating mortality and with external mycelia after exposed to conidia from $B$. bassiana. In China, $B$. bassiana was isolated from a wide-range of insects from 16 different families and two separate orders - Coleoptera and Lepidoptera (Teng, 1996; Farr \& Rossman, 2015). In Malaysia, B. bassiana was found to be pathogenic toward Metisa plana (oil palm bagworms) and proposed to use as biocontrol agent for M. plana (Ramla Ali et al., 1993). Thus far, this is the first observation of $B$. bassiana recorded to be pathogenic toward E. quadrimacula or Erotyliids. 


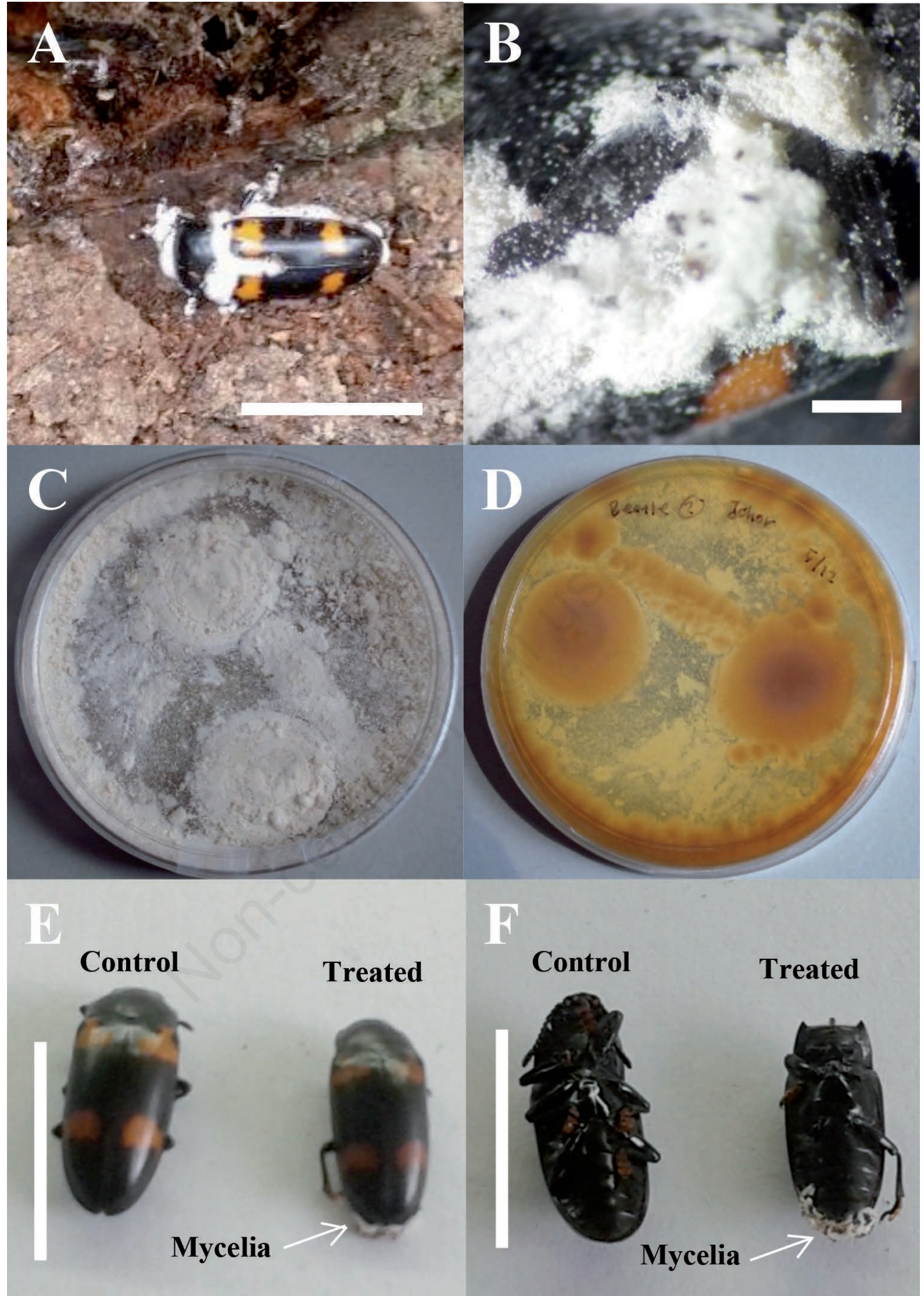

Figure 1. Beauveria bassiana and Episcapha quadrimacula: A) E. quadrimacula beetle infested with B. bassiana on oil palm trunk infected with Ganoderma boninense; B) E. quadrimacula with B. bassiana conidia and mycelia (ventral view of the beetle); C) Morphology of $B$. bassiana colony on MEA (front); D) Reverse view of $B$. bassiana colony morphology on MEA; E and F) Control and treated $E$. quadrimacula (E: dorsal view, and F: ventral view). Scale bars: A, E\&F (1 cm) and B (1 mm). 

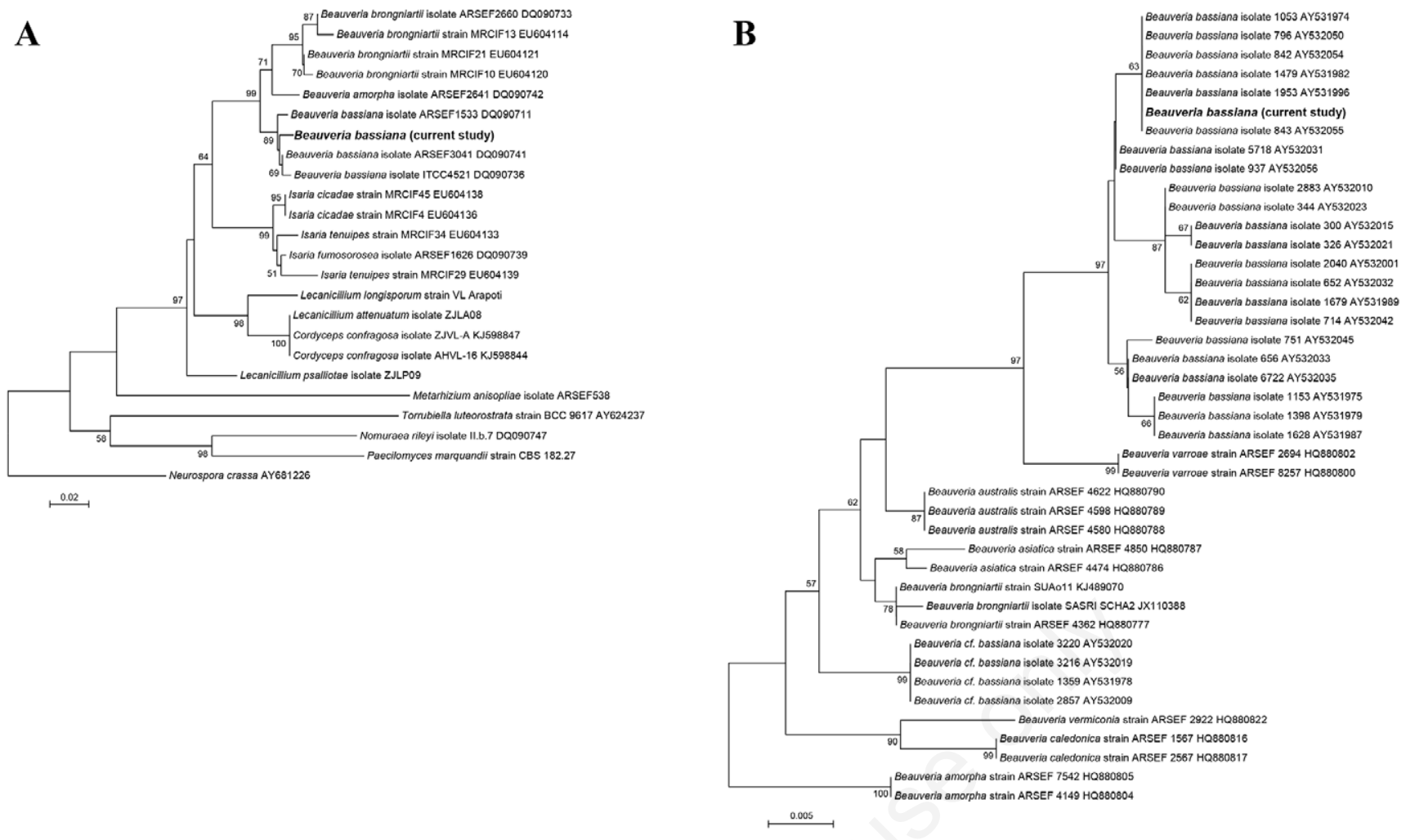

Figure 2. Phylogenetic analyses of Beauveria bassiana: neighbour joining tree illustrating the position of $B$. bassiana isolate from current study (in bold) compared with other Beauveria species and other entomopathogenic fungal species using $\beta$-tubulin (A) and ITS (B) primer sets, respectively. Only bootstrap values of $50 \%$ or greater from 1000 bootstrap replications are indicated on the respective branches. Branch lengths illustrated are with the scale bar of 0.02 and 0.005 substitutions per nucleotide position, respectively.

\section{References}

CHUNG G.F., 2011 - Management of Ganoderma diseases in oil palm plantations. - The Planter 87: 325-339.

FARR D.F., ROSSMAN A.Y., 2015 - Fungal databases. - Syst. Mycol. Microbiol. Lab., ARS, USDA. Available from: http://nt.arsgrin.gov/fungaldatabases/ Accessed: June 09, 2015.

MISHRA M., MEYER-ROCHOW V.B., 2006 - Fine structure of the com- pound eye of the fungus beetle Neotriplax lewisi (Coleoptera, Cucujiformia, Erotylidae). - Invert. Biol. 125: 265-278.

RAMLAH ALI A.S., BASRI M.W., RAMLE M., 1993 - Pathogenicity test on Beauveria bassiana (Balsamo) against oil palm bagworm (Metisa plana Wlk). - Elaeis 5: 92-101.

SEMAN I.A., 2013 - Estado actual de la investigación y desarrollo (I+D) sobre ganoderma en Malasia. - Palmas (Columbia) 34 (Special Volume 1): 100-118.

TENG S.C., 1996 - Fungi of China. - Mycotaxon, Ltd., Ithaca, NY: 586 pp. 